\title{
Komparasi Hasil Belajar IPS Peserta Didik Menggunakan Metode Think Talk Write (TTW) dan Menggunakan Metode Think Pair Share (TPS)
}

\author{
Rusmiati $^{1}$, dan Dwi Susanti ${ }^{2}$ \\ ${ }^{1,2}$ STKIP Nurul Huda OKU Timur \\ *E-mail: rusmiati@stkipnurulhuda.ac.id
}

\begin{abstract}
Abstrak: Penelitian ini dilatarbelakangi konsep bahwa pencapaian hasil belajar mata pelajaran IPS peserta didik kelas VIII belum maksimal. Sesuai permasalahan pada pembelajaran yaitu penggunaan metode yang kurang tepat, maka perlu dilakukan perubahan metode pembelajaran yang digunakan yang dalam hal ini akan dicobakan metode pembelajaran Think Talk Write (TTW) dan metode pembelajaran Think Pair Share (TPS). Tujuan dari penelitian ini adalah untuk mengetahui ada tidaknya perbedaan hasil belajar IPS antara peserta didik yang menggunakan metode Think Talk Write (TTW) dan menggunakan metode Think Pair Share (TPS. Penelitian ini merupakan bentuk penelitian komparasional. Variabel bebas penelitian ini adalah hasil belajar mata pelajaran IPS peserta didik menggunakan metode Think Talk Write, sedangkan variabel kontrol pada penelitian ini adalah hasil belajar mata pelajaran IPS menggunakan metode pembelajaran Think Pair Share. Populasi dan sampel penelitian ini seluruh peserta didik kelas VIII yang berjumlah 43 peserta didik. Teknik pengumpulan data yang digunakan adalah tes hasil belajar, sedangkan analisis data dilakukan menggunakan uji t. Hasil penelitian menyatakan terdapat perbedaan hasil belajar IPS antara peserta didik yang menggunakan metode Think Talk Write (TTW) dan menggunakan metode Think Pair Share (TPS) dengan hasil $\mathrm{t}=4,067$ dengan nilai sig. $=0,0002$, karena nilai sig. $<0,05$ maka $\mathrm{H}_{0}$ ditolak dan $\mathrm{H}_{\mathrm{a}}$ diterima.
\end{abstract}

Kata Kunci: Metode Think Talk Write, Metode Think Pair Share, Hasil Belajar IPS

UTILITY: Jurnal IImiah Pendidikan dan Ekonomi

Website : http://journal.stkipnurulhuda.ac.id/index.php/utility

Permalink: https://journal.stkipnurulhuda.ac.id/index.php/utility/article/view/283

How to cite (APA): Rusmiati, R., \& Susanti, D. (2018, February 1). Komparasi Hasil Belajar IPS Peserta Didik Menggunakan Metode Think Talk Write (TTW) dan Menggunakan Metode Think Pair Share (TPS). UTILITY: Jurnal IImiah Pendidikan Dan Ekonomi, 2(1), 44-51.

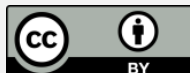

This is an open access article distributed under the terms of the Creative Commons Attribution 4.0 International License, which permits unrestricted use, distribution, and reproduction in any medium, provided the original work is properly cited.

\section{PENDAHULUAN}

Ketercapaian hasil belajar secara maksimal merupakan tujuan utama kegiatan pembelajaran yang dipengaruhi oleh berbagai macam faktor. Nasution 
(2011:177) menjelaskan bahwa faktor yang mempengaruhi belajar banyak jenisnya, namun dapat digolongkan menjadi dua yaitu faktor intern dan faktor ekstern. Faktor intern adalah faktor dalam diri individu sedang belajar meliputi faktor fisiologis dan psikologis, sedangkan faktor ekstern adalah faktor di luar individu seperti keadaan lingkungan, ketersediaan sarana, dan guru beserta cara mengelola kegiatan pembelajaran menggunakan pendekatan maupun menerapkan metode pembelajaran.

Berkaitan metode pembelajaran, Trianto (2007:51) menjelaskan, "Metode pembelajaran merupakan suatu perencanaan atau suatu pola yang digunakan sebagai pedoman merencanakan pembelajaran di kelas atau pembelajaran tutorial". Pengertian metode pembelajaran tersebut menunjukkan bahwa metode pembelajaran merupakan pedoman bagi perancang pembelajaran dan para guru dalam melaksanakan kegiatan pembelajaran. Metode pembelajaran merupakan langkah-langkah sistematis dan prosedural yang dijadikan sebagai pedoman pelaksanaan pembelajaran untuk mencapai hasil belajar secara maksimal.

Diantara metode pembelajaran yang dapat digunakan pada pembelajaran ilmu-ilmu sosial seperti pada mata pelajaran IPS adalah metode pembelajaran Think Talk Write (TTW) dan metode Think Pair Share (TPS). Metode pembelajaran Think Talk Write (TTW) merupakan salah satu tipe dari model pembelajaran kooperatif dari Slavin. Secara etimologi Think Talk Write (TTW) dalam kamus Echol (2009:152) think diartikan berfikir talk diartikan berbicara sedangkan write diartikan sebagai menulis. Berdasarkan arti etimologis tersebut dapat Think Talk Write (TTW) bisa diartikan sebagai berfikir, berbicara, dan menulis. Oleh karena itu pembelajaran menggunakan metode Think Talk Write (TTW) berarti pembelajaran yang dilaksanakan melalui kegiatan peserta didik memikirkan sesuatu yaitu materi pembelajaran, berbicara atau mengungkapkan pendapat tentang materi pembelajaran melalui kegiatan diskusi, serta menuliskan hasil pemahaman terhadap materi pembelajaran.

Secara terminologis Ansari (2010:36) mengemukakan, "Metode Think Talk Write adalah sebuah pembelajaran yang di mulai dengan berpikir melalui bahan bacaan, hasil bacaan di komunikasikan dengan presentasi, diskusi, dan kemudian membuat laporan hasil presentasi". Metode Think Talk Write (TTW) diperkenalkan oleh Huinker dan Laughin. Metode Think Talk Write (TTW) pada 
dasarnya dibangun melalui berpikir, berbicara, dan menulis sebagai bentuk aktivitas belajar peserta didik.

Selain pengertian sebagaimana tersebut, Huda (2013:138) menjelaskan bahwa metode Think Talk Write adalah metode pembelajaran yang dimulai dari keterlibatan peserta didik dalam berfikir atau berdialog dengan diri sendiri setelah proses membaca, selanjutnya berbicara dan membagi ide (sharing) dengan teman sebelum menulis. Suasana seperti ini lebih efektif jika dilakukan dalam kelompok heterogen dengan 3-5 peserta didik. Peserta didik dalam kelompok diminta membaca, membuat catatan kecil, menjelaskan, mendengarkan dan membagi ide bersama teman kemudian mengungkapkannya melalui tulisan. dan Think Pair Share (TPS) merupakan salah satu bentuk metode pembelajaran Cooperative Learning. Think Pair Share dikembangkan oleh Frank Lyman dari Universitas Maryland pada tahun 1985. Think Pair Share merupakan salah satu metode pembelajaran kooperatif sederhana. Teknik ini memberi kesempatan pada peserta didik untuk bekerja sendiri serta bekerja sama dengan orang lain. Zaini (2013:82) menjelaskan, "Think Pair Share adalah salah satu bentuk metode pembelajaran yang memberi kesempatan kepada setiap peserta didik untuk menunjukkan partisipasi kepada orang lain". Menurut Huda (2013:206), "Metode pembelajaran Think Pair Share adalah metode yang memperkenalkan gagasan tentang waktu tunggu atau berfikir atau wait or think time pada elemen pembelajaran kooperatif".

Trianto (2010:81) mengatakan, "Think Pair Share atau berpikir berpasangan berbagi adalah merupakan jenis pembelajaran kooperatif dirancang untuk mempengaruhi interaksi peserta didik". Penjelasan tersebut menunjukkan bahwa Think Pair Share adalah metode pembelajaran kooperatif memiliki prosedur ditetapkan secara eksplisit memberikan waktu lebih banyak kepada peserta didik untuk memikirkan secara mendalam tentang materi dijelaskan atau dialami pada proses berfikir, menjawab, dan saling membantu satu sama lain.

Kegiatan belajar merupakan suatu proses usaha yang dilakukan seseorang untuk memperoleh suatu perubahan tingkah laku baru secara keseluruhan sebagai hasil kegiatan belajarnya. Berkaitan pengertian hasil belajar, Nasution (2011:17) mengemukakan, "Hasil belajar adalah kesempurnaan dicapai seseorang dalam berfikir, merasa serta berbuat selama kegiatan belajar". Sementara itu Tu'u (2007:75) bahwa, "Hasil belajar adalah hasil yang dicapai 
seseorang ketika mengerjakan tugas atau kegiatan belajar tertentu". Sementara menurut Sudjana (2010:22), "Hasil belajar adalah kemampuan yang dimiliki peserta didik setelah menerima pengalaman belajar.

Dalam rangka meningkatkan dan memperbaiki hasil belajar maka pendidik harus selalu menerapkan metode yang bervariasi diantaranya TTW dan TPS. Kedua metode pembelajaran ini mempunyai kelebihan diantaranya peserta didik harus mempunyai tujuan sama yaitu memahami materi pembelajaran sehingga peserta didik akan terpacu untuk belajar. Pada tahap diskusi, peserta didik membandingkan, menghubungkan sebab akibat, memberi alasan, berpendapat, menciptakan, menerapkan, serta menganalisis materi. Tahap terakhir yaitu menarik kesimpulan peserta didik menyimpulkan, mensintesis, kemudian mengevalusi. Dengan demikian peserta didik akan terlibat secara aktif dalam kegiatan pembelajaran secara keseluruhan sehingga hasil belajar dapat maksimal.

\section{METODE}

Penelitian ini memiliki satu variabel bebas dan satu variabel terikat. Variabel bebas penelitian ini adalah hasil belajar mata pelajaran IPS peserta didik menggunakan metode Think Talk Write, sedangkan variabel kontrol pada penelitian ini adalah hasil belajar mata pelajaran IPS menggunakan metode pembelajaran Think Pair Share.

Penelitian ini adalah penelitian komparatif. Emzir (2011:199) menjelaskan, "penelitian komparatif atau ex post facto adalah penelitian di mana peneliti berusaha menentukan penyebab atau alasan untuk keberadaan perbedaan dalam perilaku atau status dalam kelompok individu". Komparasi pada penelitian ini dilakukan terhadap hasil belajar peserta didik menggunakan metode Think Talk Write (TTW) dan peserta didik menggunakan metode Think Pair Share (TPS).

Desain penelitian yang digunakan adalah penelitian eksperimen murni atau true experimental. Sugiyono (2010:75), "Penelitian eksperimen murni atau True Experimental adalah suatu bentuk penelitian dimana peneliti dapat mengontrol semua variabel luar yang mempengaruhi jalannya eksperimen". Penelitian eksperimen murni merupakan bentuk penelitian yang hanya 
memperhatikan treatment pada objek penelitian. Desain penelitian yang digunakan adalah Postest Only Control Group Design tanpa adanya pretest.

Populasi pada penelitian ini adalah seluruh peserta didik kelas VIII MTs Plus Al Fattah Kecamatan Buay Madang Timur yang berjumlah 43 peserta didik dan terbagi dalam dua kelas. Karena jumlah populasi kurang dari 100, maka seluruh populasi dijadikan sebagai sampel dalam penelitian. Teknik pengumpulan data yang digunakan pada penelitian ini adalah tes. Sebelum digunakan instrumen tes diuji terlebih dahulu tingkat kevalidan menggunakan product moment, reliabilitas menggunakan KR-20, tingkat kesukaran dan daya pembeda soal. Setelah data terkumpul, dilakukan uji prasyarat analisis data yaitu normalitas menggunakan rumus chi square dan uji homogenitas menggunakan kesamaan varian. Setelah data dinyatakan normal, maka dilakukan analisis data menggunakan uji t.

\section{HASIL DAN PEMBAHASAN}

Hasil belajar IPS peserta didik menggunakan meode Think Talk Write diketahui menggunakan instrumen tes. Instrumen Tes disusun 20 nomor berbentuk pilihan ganda dengan 5 opsi jawaban yaitu a, b, c, d dan e. Jika peserta didik menjawab benar mendapatkan skor 1 dan jika salah mendapatkan skor 0 .

Berdasarkan analisis hasil tes peserta didik yang pembelajarannya menggunakan metode Think Talk Write diketahui bahwa hasil belajar IPS peserta didik adalah sedang. Hal tersebut dibuktikan dari hasil tes yang menunjukkan dari 21 peserta didik terdapat 15 peserta didik atau $71,43 \%$ memperoleh nilai kategori sedang. Data juga menunjukkan dari 21 peserta didik terdapat 5 peserta didik atau 23,80\% memperoleh nilai kategori tinggi. Adapun 1 peserta didik lain atau 4,76\% memperoleh nilai kategori rendah. Hasil analisis data hasil tes mata pelajaran IPS peserta didik kelas VIII MTs Plus Al Fattah Kecamatan Buay Madang Timur yang pembelajarannya menggunakan metode Think Talk Write menunjukkan bahwa metode Think Talk Write efektif diterapkan pada mata pelajaran IPS. Pada metode Think Talk Write terlibat aspek reaksi emosional didalamnya dan metode Think Talk Write merupakan suatu metode pembelajaran yang dapat membantu peserta didik dalam mempelajari keterampilan dasar dan memperoleh informasi yang dapat 
diajarkan selangkah demi selangkah sampai akhirnya dapat menguasai materi pembelajaran secara maksimal.

Berdasarkan analisis hasil tes peserta didik yang pembelajarannya menggunakan metode Think Pair Share diketahui bahwa hasil belajar IPS peserta didik adalah sedang. Hal tersebut dibuktikan dari hasil tes yang menunjukkan dari 22 peserta didik terdapat 17 peserta didik atau 77,27\% memperoleh nilai kategori sedang. Data juga menunjukkan dari 22 peserta didik terdapat 1 peserta didik atau 4,55\% memperoleh nilai kategori tinggi. Adapun 4 peserta didik lain atau 18,18\% memperoleh nilai kategori rendah.

Data sebagaimana tersebut menunjukkan bahwa metode Think Pair Share kurang efektif diterapkan pada mata pelajaran IPS. Hal tersebut terlihat dari adanya 4 peserta didik atau $18,18 \%$ yang memperoleh nilai kategori rendah. Hasil penelitian juga menunjukkan bahwa selama kegiatan pembelajaran menggunakan metode Think Pair Share, peserta didik bersikap kurang aktif terutama dalam berbagi. Kegiatan pembelajaran menjadi kurang efektif ketika peserta didik memperoleh pasangan yang tidak berjalan sesuai rencana.

Setelah masing-masing data hasil tes baik kelas menggunakan metode Think Talk Write maupun menggunakan metode Think Pair Share diketahui, langkah selanjutnya adalah melakukan uji hipotesis. Pengujian hipotesis dilakukan menggunakan uji $\mathrm{t}$. Hasil uji hipotesis diperoleh nilai $\mathrm{t}=4,067$ dengan nilai sig. $=0,0002$, karena nilai sig. $<0,05$ maka $\mathrm{H}_{\mathrm{o}}$ yang menyatakan tidak terdapat perbedaan hasil belajar IPS yang signifikan antara peserta didik menggunakan metode Think Talk Write (TTW) dan menggunakan metode Think Pair Share (TPS) di kelas VIII MTs Plus Al Fattah Kecamatan Buay Madang Timur ditolak, sedangkan $\mathrm{H}_{\mathrm{a}}$ yang menyatakan terdapat perbedaan hasil belajar IPS yang signifikan antara peserta didik menggunakan metode Think Talk Write (TTW) dan menggunakan metode Think Pair Share (TPS) di kelas VIII MTs Plus Al Fattah Kecamatan Buay Madang Timur diterima.

\section{SIMPULAN}

Berdasarkan analisis data dan pembahasan hasil penelitian ini dapat disimpulkan Terdapat perbedaan hasil belajar IPS antara peserta didik yang menggunakan metode Thinb Talk Write (TTW) dan menggunakan metode Think Pair Share (TPS) di kelas VIII MTs Plus Al Fattah Kecamatan Buay 
Madang Timur dengan nilai $\mathrm{t}=4,067$ dengan nilai sig. $=0,0002$, karena nilai sig. $<0,05$ maka $\mathrm{H}_{0}$ ditolak dan $\mathrm{H}_{\mathrm{a}}$ diterima.

\section{SARAN}

Berdasarkan hasil penelitian yang telah dilaksanakan menunjukkan adanya perbedaan hasil belajar IPS antara peserta didik yang menggunakan metode Thinb Talk Write (TTW) dan menggunakan metode Think Pair Share (TPS) , maka dapat disarankan sebagai berikut: 1. Peserta didik dalam mengikuti kegiatan pembelajaran IPS menggunakan metode Think Talk Write (TTW) hendaknya lebih aktif dan kreatif dalam mencatat materi yang dianggap perlu, mengemukakan pendapat dan berfikir sesuai materi pembelajaran agar dapat memahami materi pembelajaran dan meraih hasil belajar secara maksimal. Apabila guru mempergunakan metode Think Pair Share (TPS) hendaknya peserta didik hendaknya dapat benar-benar saling membantu pasangannya dalam memahami materi pembelajaran sehingga seluruh peserta didik akan dapat memahami materi pembelajaran dan meraih hasil belajar secara maksimal.

Pendidik hendaknya dapat menerapkan metode Think Talk Write (TTW) pada pembelajaran IPS secara efektif sesuai dengan tingkat perkembangan dan kemampuan peserta didik agar materi pembelajaran dapat benar-benar tersampaikan kepada peserta didik dan tujuan pembelajaran dapat tercapai dengan baik. Guru dalam melaksanakan pembelajaran menggunakan metode Think Pair Share (TPS) hendaknya dapat memilih peserta didik yang benarbenar heterogen dari segi kemampuan sehingga akan terjalin kegiatan pembelajaran dengan saling berbagi atau Share secara maksimal dan seluruh peserta didik dapat memahami materi pembelajaran. 3. Sekolah hendaknya dapat memberikan pelayanan pada kegiatan pembelajaran menggunakan metode Think Talk Write (TTW) dan metode Think Pair Share (TPS) dengan menyediakan berbagai sarana penunjang agar kegiatan pembelajaran dapat berjalan dengan baik. Sekolah hendaknya dapat memacu berbagai kegiatan eksperimen pada semua mata pelajaran dan menginstruksikan guru untuk membuat portofolio berbentuk laporan eksperimen supaya dapat dijadikan sebagai pedoman guru maupun peserta didik dalam melaksanakan eksperimen dalam pembelajaran. 


\section{UCAPAN TERIMAKASIH}

Ucapan terima kasih ditujukan kepada Ketua STKIP Nurul Huda OKU Timur, Ketua LPPM STKIP Nurul Huda, Tim Jurnal Utility, Kepala MTs Plus Al-Fattah dan segenap dewan Dosen staf yang tidak dapat disebutkan satu persatu.

\section{REFERENSI}

Ansari, A. (2010). Metode Pembelajaran Kontemporer. Malang: YPIF Malang.

Emzir. (2011). Metodologi Penelitian Pendidikan Kuantitatif \& Kualitatif. Jakarta: Raja Grafindo Persada.

Huda, M. (2013). Model-model Pengajaran dan Pembelajaran. Yogyakarta: Pustaka Pelajar.

Echol, J. (2009). English Grammar. Jakarta: Raja Grafindo Persada.

Nasution, S. (2011). Kurikulum dan Pembelajaran. Jakarta: Bumi Aksara.

Sudjana, N. (2010). Ilmu Pendidikan. Bandung: Remaja Rosdakarya.

Sugiyono. (2010). Metode Penelitian Kualitatif, Kuantitatif, dan $R \& B$. Bandung: Alfabeta

Trianto. (2007). Model-model Pembelajaran Inovatif Berorientasi Konstruktivistik. Jakarta: Prestasi Pustaka Publisher.

Trianto. (2010). Model Pembelajaran Terpadu. Jakarta: Bumi Aksara.

Tu'u, T. (2007). Belajar dan Pembelajaran. Jakarta: Raja Grafindo Persada.

Zaini, A. (2013). Model-model Pembelajaran. Bandung: Kusuma Bangsa. 